\title{
Peningkatan Hasil Belajar Matematika Tentang Pecahan Melalui Model Interaktif pada Siswa SD
}

\author{
Rokhaniyah \\ UPK Jatilawang Banyumas \\ Jl. Pramuka, Tunjung Wetan, Tunjung, Kec. Jatilawang, Kabupaten Banyumas, Jawa \\ Tengah \\ Email: bdmartono7@gmail.com
}

\begin{abstract}
Abstrak
Penelitian ini bertujuan untuk mengetahui permasalahan yang terjadi dalam pembelajaran Matematika tentang pecahan dan mencari cara pemecahan masalah tersebut. Fokus dari masalah yang diteliti adalah "Bagaimana Cara meningkatkan Hasil Belajar Matematika tentang Pecahan Siswa Kelas V SD Negeri Tanjung Kulon Kecamatan Jatilawang Kabupaten Banyumas". Penelitian ini dilakukan dengan menggunakan observasi dari teman sejawat, indikator peningkatan hasil belajar dengan data kuantitatif. Sebagai subjek penelitian adalah kelas V SD Negeri Tunjung Kulon. Dengan jumlah 20 siswa, waktu pelaksanaan tindakan terdiri dari tiga siklus tiap siklusnya satu pertemuan . Menggunakan Model Pembelajaran Interaktif. Hasil penelitian menunjukan adanya peningkatan hasil belajar, kondisi awal tingkat ketuntasannya hanya 20\% setelah diadakan perbaikan menjadi $85 \%$ dapat dinyatakan tindakan perbaiaka telah berhasil.
\end{abstract}

Kata Kunci: Pembelajaran Interaktif, Hasil Belajar, Matematika.

\begin{abstract}
This study aims to determine the problems that occur in learning mathematics about fractions and find ways to solve these problems. The focus of the problem under study is "How to improve Mathematics Learning Outcomes of Fractions of Class V Students in Tanjung Kulon Elementary School, Jatilawang District, Banyumas Regency". This research was conducted using observations from peers, an indicator of increased learning outcomes with quantitative data. As the subject of the study was the fifth grade of SD Tunjung Kulon Elementary School. With a total of 20 students, the time for implementing the action consists of three cycles per cycle. Using the Interactive Learning Model. The results showed an increase in learning outcomes, the initial condition of the completeness level was only $20 \%$ after the improvement was made to be $85 \%$, it could be stated that the improvement was successful.
\end{abstract}

Keywords: Interactive Learning, Learning Outcomes, Mathematics

\section{PENDAHULUAN}

Dalam pembelajaran Matematika tentang pecahan yang terjadi di kelas V SD Negeri Tunjungkulon, perencanaan program mengajar dan pengelolaan kelas sudah tersusun dengan cukup baik. Namun siswa kurang merespon pertanyaan dari guru, siswa melamun ketika proses pembelajaran sedang berlangsung dan hasil belajar $70 \%$ siswa $\underline{\text { masih dibawah standar minimal. Hal ini dapat dilihat dari hasil tes formatif siswa, dari } 20}$ 
siswa yang mendapat nilai diatas Kriteria Ketuntasan Minimal hanya 30\% atau 6 siswa. Dengan kata lain $70 \%$ atau 14 siswa memperoleh nilai dibawah Kriteria Ketuntasan Minimal. Dari pernyataan diatas dapat dilihat bahwa prestasi dan hasil belajar siswa kelas V SD Negeri Tanjug Kulon Kecamatan JatilawangKabupaten Banyumas pada pelajaran matematika tentang pecahan sangat rendah.Dari identifikasi masalah diatas, peneliti memfokuskan masalah pada rendahnya hasil belajar siwa. Peneliti merefleksi diri sehingga dapat diketahui bahwa kemungkinan faktor penyebab rendahnya hasil belajar siswa SD Negeri Tanjung Kulon Kecamatan JatilawangKabupaten Banyumas dalam mata pelajaran matematika tentang pecahan adalah:

1) Guru menerapakan model yang kurang tepat

2) Rendahnya tingkat partisipasi aktif siswa dalam pembelajaran

3) Guru kurang melibatkan siswa untuk aktif dalam proses pembelajaran.

Berdasarkan identifikasi masalah tersebut peneliti mengambil kesimpulan awal tentang masalah diatas bahwa model pembelajaran yang diterapkan belum menyentuh kebutuhan siswa. Penerapan model pembelajaran interaktif dapat sebagai strategi untuk meningkatkan hasil belajar matematika tentang pecahan siswa kelas V SD Negeri Tanjung Kulon Kecamatan Jatilawang Kabupaten Banyumas.

Banyak definisi ahli tentang belajar namun berdasarkan beberapa definisi tentang belajar dapat disimpulkan bahwa belajar merupakan segenap rangkaian kegiatan atau aktivitas yang dilakukan secara sadar oleh seseorang dan mengakibatkan perubahan dalam dirinya berupa penambahan pengetahuan atau kemahiran berdasarkan alat indera dan pengalamannya. Oleh sebab itu apabila setelah belajar peserta didik tidak ada perubahan dalam tingkah laku yang positif dalam arti tidak memiliki kecakapan baru serta wawasan pengetahuannya tidak bertambah maka dikatakan bahwa belajarnya belum sempurna. Berdasarkan pendapat diatas belajar dapat diartikan suatu kegiatan yang dilakukan untuk memperoleh ilmu pengetahuan melalui aktifitas mental/psikis yang berlangsung dalam interaksi aktif dengan lingkungan yang mengakibatkan perubahan prilaku pribadi yang bersifat pemanen atau tetap. Belajar tidak hanya bias dilakukan di sekolahan, tetapi kita bias belajar dimanapun tempat. Dengan belajar kita dapat melakukan perubahan yang akan berdampak pada kehidupan kita sekarang dan masa yang akan datang. Matematika bukan hanya sekedar segala sesuatu yang berhubungan dengan angka dan bilangan. Matematika adalah ilmu yang mempelajari tentang besaran, struktur, bangun ruang, dan perubahanperubahan yang pada suatu bilangan. Matematika berasal dari bahasa Yunani $\underline{\text { Mathematikos yang artinya ilmu pasti. Dalam bahasa belanda matematika di sebut sebagai }}$ 
Wiskunde yang artinya ilmu tentang belajar. Dalam kamus besar bahasa Indonesia, definisi matematika adalah ilmu tentang bilangan dan segala sesuatu yang berhubungan dengannya yang mencangkup segala bentuk prosedur operasional yang digunakan dalam menyelesaikan masalah mengenai bilangan. Seorang yang ahli dalam bidang matematika di sebut sebagai Matematikawan atau matematikus. Segala hal yang bersangkutan dan berhubungan dengan matematika di sebut sebagai matematis. Matematis juga di gunakan untuk menyebut sesuatu secara sangat pasti dan sangat tepat. Herman Hudoyo menyatakan bahwa matematika berkenaan dengan ide-ide abstrak yang diberi simbol-simbol itu tersusun secara hirarkis dan penalarannya deduktif, sehingga belajar matematika itu merupakan kegiatan mental yang tinggi. Mempelajari konsep B yang mendasarkan kepada konsep A, seseorang perlu mamahami terlebih dahulu konsep A. Tanpa memahami konsep A, tidak mungkin orang itu memahami konsep B. Ini berarti mempelajari matematika haruslah bertahap dan berurutan serta mendasarkan kepada pengalaman terdahulu. Karena itu untuk mempelajari suatu materi matematika yang baru pengalaman belajar yang lalu dari seseorang itu akan mempengaruhi terjadinya proses belajar materi matematika tersebut.

Sebelum mempelajari matematika lebih dalam, alangkah baiknya untuk mengetahui pengertian matematika menurut para ahli. Pengertian matematika tersebut dapat dijadikan sebagai acuan dasar untuk mempelajari matematika yang lebih dalam. Berikut pengertian matematika menurut kurikulum pendidikan, antara lain :

a. Kurikulum 2004 Matematika ialah bahan kajian yang mempunyai suatu objek abstrak serta dibangun dengan melalui proses penalaran deduktif, yaitu kebenaran suatu konsep yang diperoleh sebagai akibat logis dari suatu kebenaran yang sebelumnya diterima sehingga memiliki keterkaitan antara konsep yang ada dalam matematika bersifat sangat kuat serta jelas.

b. Kurikulum 2006 Matematika adalah ilmu universal yang mendasari dari perkembangan teknologi modern saat ini, memiliki peran yang penting dalam berbagai disiplin serta untuk memajukan daya pikir manusia. Perkembangan pesat pada bidang teknologi informasi serta komunikasi saat ini dilandasi karena perkembangan matematika pada bidang teori bilangan, analisis, teori peluang, aljabar, serta diskrit. Agar dapat menguasai serta untuk menciptakan teknologi pada masa yang akan datang, maka diperlukan penguasaan dibidang matematika yang kuat sejak dini.

Matematika memiliki peran yang penting dalam kehidupan kita. Siswa memerlukan $\underline{\text { matematika untuk menyelesaikan suatu masalah yang terjadi disekitarnya. Gatot }}$ 
Muhsetyo dkk (2012 : 1.26) Pembelajaran matematika adalah proses pemberian pengalaman belajar kepada peserta didik serangkaian kegiatan yang yang terencana sehingga peserta didik memperoleh kompetensi tentang bahan matematika yang dipelajari.

\section{METODE PENELITIAN}

Salah satu komponen yang menentukan ketercapaian kompetensi adalah penggunaan strategi pembelajaran matematika yang sesuai dengan: 1)Topik yang sedang dibicarakan, 2) Tingkat perkembangan intelektual peserta didik, 3) Perinsip dan teori belajar, 4) Keterlibatan aktif peserta didik, 5) Keterkaiatan dengan kehidupan peserta didik sehari-hari, 6) Pengembangan dan pemahaman penalaran matematis. Pembelajaran Interaktif merupakan salah satu model pembelajaran yang sangat penting untuk meningkatkan kemampuan akademik siswa. Pembelajaran terdapat Komponenkomponen pembelajaran ditinjau dari pendekatan sistem, maka dalam prosesnya suatu pembelajaran akan melibatkan berbagai komponen, diantaranya: tujuan, guru, peserta didik, materi, metode, media serta evaluasi.

Model pembelajaran interaktif sering dikenal dengan nama pendekatan pertanyaan anak. Model ini dirancang agar siswa akan bertanya dan kemudian menemukan jawaban pertanyaan mereka sendiri (Faire \& Cosgrove dalam Harlen, 1992). Meskipun siswa mengajukan pertanyaan dalam kegiatan bebas, pertanyaan-pertanyaan tersebut akan terlalu melebar dan seringkali kabur sehingga kurang terfokus. Guru perlu mengambil langkah khusus untuk mengumpulkan, memilah, dan mengubah pertanyaan-pertanyaan tersebut ke dalam kegiatan khusus. Pembelajaran interaktif merinci langkah-langkah ini dan menampilkan suatu struktur untuk suatu mata pelajaran yang melibatkan pengumpulan dan pertimbangan terhadap pertanyaan-pertanyaan siswa sebagai pusatnya (Harlen, 1992:4850). Terdapat beberapa faktor yang perlu diperhatikan oleh guru agar siswa terlibat aktif dalam kegiatan pembelajaran. Yakni aktivitas merumuskan pertanyaan dan menjawabnya. Faktor-faktor tersebut adalah sebagai berikut.

1. Faktor Minat dan Perhatian

Minat adalah suatu rasa lebih suka dan rasa keterikatan pada suatu hal atau aktifitas,tanpa ada yang memerintah. Suatu minat dapat diekspresikan melalui suatu pernyataan yang menunjukkan bahwa siswa lebih menyukai suatu hal dari pada hal lainnya. Mengembangkan suatu minat terhadap sesuatu pada dasarnya adalah membantu siswa melihat bagaimana hubungan antara materi yang diharapkan untuk dipelajari atau 
dilakukandengan dirinya sendiri sebagai dirinya sendiri sebagai individu. Semakin kuat atau dekat hubungan tersebut, semakin besar minat itu.

\section{Faktor Motivasi}

Kata motivasi berasal dari kata "motif", yang berarti alasan melakukan sesuatu, sebuah kekuatan yang menyebabkan seseorang bergerak melakukan suatu kegiatan. Dalam Kamus Besar Bahasa Indonesia, (Depdikbud, 1996:593) motivasi didefinisikan sebagai dorongan yang timbul pada diri seseorang sadar atau tidak sadar untuk melakukan suatu tindakan dengan tujuan tertentu.

\section{Faktor Latar atau Konteks}

Belajar pada realita akan menarik bagi siswa, belajar dimulai dari yang sederhana dapat memotivasi siswa, dan belajar berdasarkan pengalaman siswa dapat mengaktifkan siswa..

\section{Faktor Perbedaan Individu}

Pada hakekatnya, siswa adalah individu yang unik yang memiliki karakteristik yang berdeda-beda, baik pengetahuan, minat, bakat, sifat, kemampuan, dan latar belakang. Perbedaan tersebut dapat mempengaruhi kegiatan pembelajaran. Secara umum, siswa memiliki perbadaan secra vertikal dan secara horizontal. Perbedaan vertikal berkenaan dengan kecardasan (IQ), dan perbedaan horizontal berkenaan degan bakat (talenta) dan minat..

\section{Faktor Sosialisasi}

Sosialisasi atau proses hubungan social, pada masa anak-anak sedang tumbuh yang ditandai dengan keinginannya untuk selalu berusaha menjalin hubungan dengan teman temannya. Bermain merupakan kebutuhan bagi siswa yang sehat kerena bermain merupakan keaktifan yang menimbulkan kegembiraan dan menyenangkan. Bermain disini lebih dimaksudkan pada kegiatan pembelajaran yang berlangsung dalam suasana menyenangkan sehingga akan mendorong siswa aktif belajar., selain itu pengetahuan, keterampilan, sikap dan daya fantasi siswa akan berkembang. Suasana senang dan gembira dalam kegiatan pembelajaran. Artinya, guru harus menciptakan suasana yang menyenangkan bagi siswa.

\section{Faktor Belajar Sambil Bekerja}

Konsep belajar sambil bekerja pertama kali dikemukakan oleh Dewey melalui metode proyek, Aktivitas belajar tersebut dikelompokan kedalam lima kategori, yaitu :

a. Aktivitas (visual activities), seperti membaca, menulis, melakukan eksperimen, dan demonstrasi. 
b. Aktivitas lisan (oral activities), seperti bercerita, membaca sajak, tanya jawab, dan diskusi;

c. Aktivitas mendengarkan (listening activities), seperti mendengarkan penjelasan guru, mendengarkan ceramah dan pengarahan;

d. Aktivitas gerek (motor activities), seperti simulasi, bermain peran, membuat peta dan table dan grafik;

e. Aktivitas menulis (writing activities), seperti mengarang, membuat ringkasan, dan membuat laporan atau makalah.

7. Faktor Inkuiri

8. Faktor Pemecahan Masalah

Setiap siswa menyukai tantangan (sense of chalanger), demikian pula halnya dalam belajar. Belajar yang memiliki tantangan sesuai tingkat kemampuan siswa akan mendorong mereka untuk belajar.

Gambar model pembelajaran interaktif

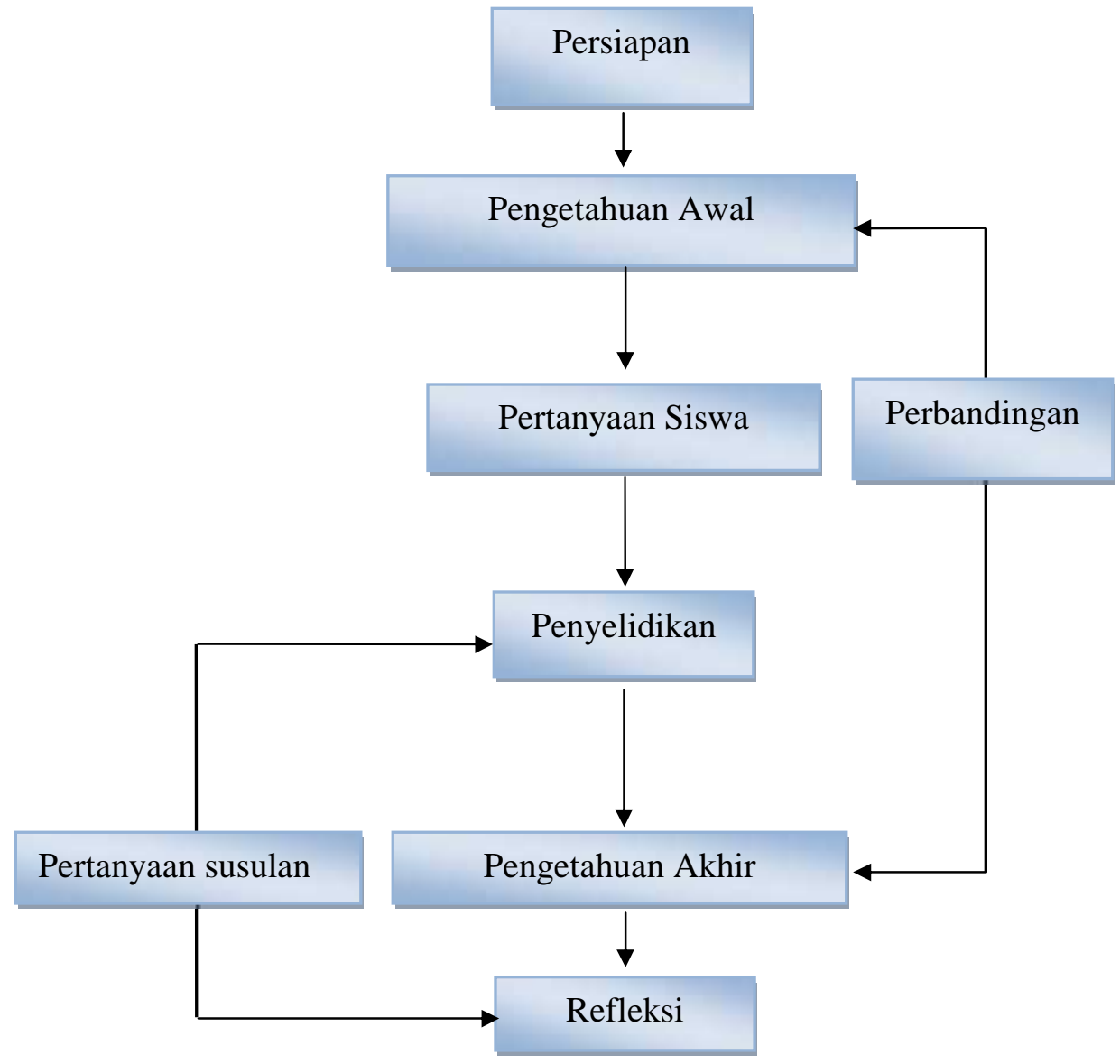

Gambar 1 Langkah-langkah pembelajaran Interaktif 


\section{HASIL DAN PEMBAHASAN}

Siklus 1, II dan III

Hasil perbaikan pembelajaran yang peneliti lakukan dengan menggunakan Model Pembelajaran Interaktif di kelas V SD Negeri TUNJUNG KULON Kecamatan JatilawangKabupaten Banyumas pada pra siklus, siklus pertama, siklus kedua dan siklus ketiga menunjukan peningkatan pada tiap siklusnya. Dalam tiga siklus perbaikan pembelajaran, setiap siklusnya dilaksanakan dalam satu kali pertemuan, dengan pokok bahasan :

a. Mengubah pecahan ke bentuk pecahan lain

b. Menjumlah dan mengurangkan pecahan

Pada setiap siklus terjadi peningkatan keaktifan siswa dalam proses pembelajaran. Rekapitulasi keaktifan siswa dalam pembelajaran Matematika tentang pecahan di kelas $\mathrm{V}$ SD Negeri Tanjung Kulon yang meliputi keaktifan bertanya, menjawab, menanggapi dan bekerja sama dapat dilihat pada tabel dibawah ini.

Tabel 1 Rekapitulasi Keaktifan siswa Dalam Pembelajaran Matematika Tentang Pecahan di Kelas V SD Negeri Tunjungkulon

\begin{tabular}{|l|l|r|r|r|}
\hline \multirow{2}{*}{ No } & \multirow{2}{*}{ Uraian } & \multicolumn{2}{|c|}{ Keaktifan Siswa } & \multirow{2}{*}{ Keterangan } \\
\cline { 3 - 5 } & & 6 & $30 \%$ & Rendah \\
\hline 1 & Pra Siklus & 13 & $65 \%$ & Rendah \\
3 & Siklus I & 19 & $95 \%$ & Sedang \\
\hline
\end{tabular}

Data pada tabel 1 dapat dilihat bahwa pada prasiklus siswa yang terlibat aktif sangat rendah yaitu hanya 6 dari 20 siswa atau hanya 30\%. Pada siklus I ada peningkatan keaktifan siswa meski belum cukup tinggi yaitu 13 dari 20 siswa atau $65 \%$. Pada siklus II terjadi peningkatan lagi yaitu 19 dari 20 siswa atau $95 \%$.

Gambar 1 Rekapitulasi Keaktifan siswa Dalam Pembelajaran Matematika Tentang Pecahan di Kelas V SD Negeri 1 Dermaji

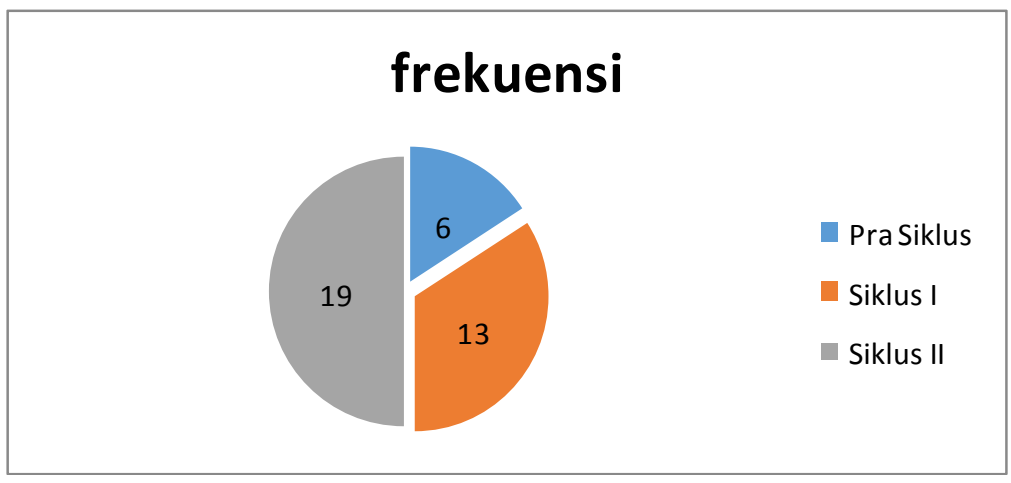

Gambar 2. Hasil Tes Formatif Mata Pelajaran Matematika Tentang Pecahan 
Pra Siklus, Siklus I, Siklus II.

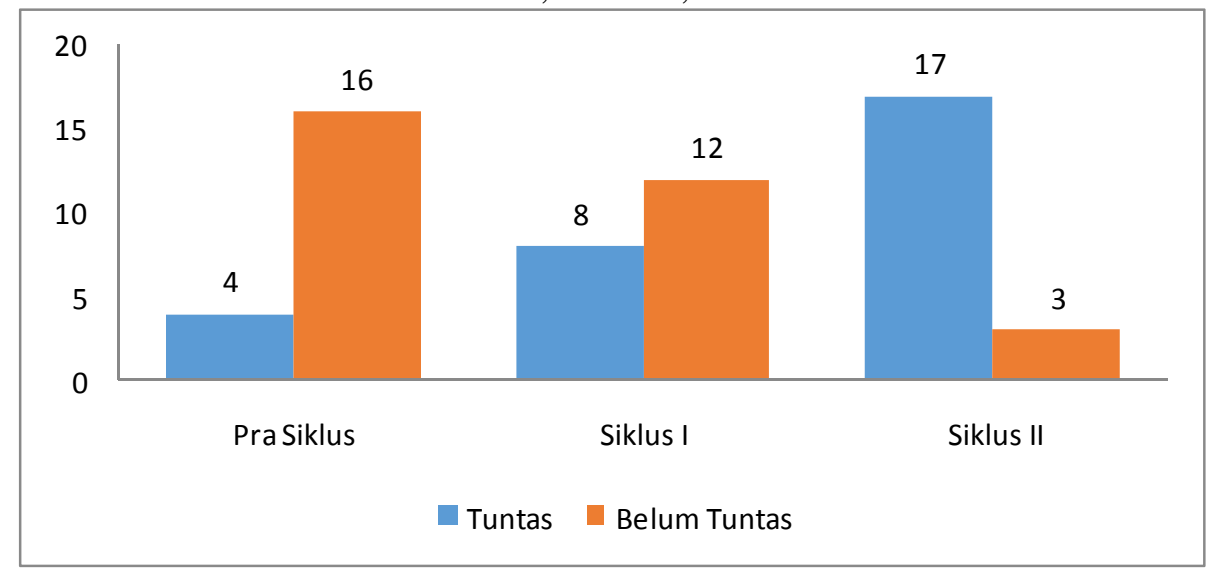

Berdasarkan gambar 2. dapat dilihat hasil perubahan ketuntasan belajar yang dicapai siswa kelas V SD Negeri Tanjung Kulon Kecamatan JatilawangKabupaten Banyumas mulai dari pra siklus sampai siklus kedua. Sebagian mengalami peningkatan, adapun peningkatan tersebut dapat dirinci sebagai berikut :

1) Pada pra siklus, siswa yang belum tuntas sebanyak 16 siswa dari 20 siswa atau $80 \%$.

2) Pada siklus I, siswa yang belum tuntas sebanyak 12 siswa dari 20 siswa atau $60 \%$.

3) Pada siklus II, siswa yang belum tuntas sebanyak 3 siswa dari 20 siswa atau $15 \%$.

Siswa yang dapat menguasai materi pembelajaran mengalami peningkatan yang cukup menggembirakan, yaitu :

1) Pada pra siklus, siswa yang tuntas sebanyak 4 siswa dari 20 siswa atau $20 \%$.

2) Pada siklus I, siswa yang tuntas sebanyak 8 siswa dari 20 siswa atau $40 \%$.

3) Pada siklus II, siswa yang tuntas sebanyak 17 siswa dari 20 siswa atau $85 \%$.

\section{KESIMPULAN}

Berdasarkan hasil penelitian dan pembahasan yang diperoleh dari penelitian tindakan kelas mata pelajaran Matematika dapat ditarik kesimpulan bahwa dengan penggunaan metode pembelajran interaktif dalam pembelajarn matematika pada siswa kelas V SD Negeri Tanjung Kulon Kecamatan JatilawangKabupaten Banyumas ternyata dapat meningkatkan hasil belajar siswa. Hal ini dapat ditunjukan bahwa pada setiap siklus terjadi peningkatan. Pada prasiklus rata-rata hasil belajar siswa kelas V SD Negeri Tanjung Kulon Kecamatan JatilawangKabupaten Banyumas adalah 43,5. Pada siklus pertama ratarata hasil belajar siswa mengalami peningkatan adalah 60. Pada siklus kedua rata-rata hasil belajar siswa adalah 72,5. Jika dilihat dari ketuntasan belajar secara umum kelas $\mathrm{V}$ SD Negeri Tanjung Kulon telah tuntas $85 \%$. 


\section{SARAN}

Pada penelitian yang akan datang perlu diperdalam lagi terkait metode pembelajaran interaktif dan karakter siswa

\section{DAFTAR PUSTAKA}

Angie. 2010. Karakteristik Siswa Kelas 5-6. Diunduh 26 Maret 2014 dari http://labolatoriumpendidikan.wordpress.com/2010/10/10/karaktristik-siswa-kelas$5-6 /$

Conny R. Semiawan. 1999. Perkembangan dan Belajar Peserta Didik. Depdikbud.

Djamarah, Syaiful Bahri. 2002. Rahasia Sukses Belajar. Jakarta : PT. Rineka Cipta

Djamarah, Syaiful Bahri. 2005. Guru dan Anak Didik dalam Interaksi Edukatif. Jakarta: Rineka Cipta.. 2011. Psikologi Belajar. Jakarta: Rineka Cipta.

Muhsetyo, Gatot dkk. 2012. Pembelajaran Matematika SD. Tanggerang Selatan: Universitas Terbuka

Satori, Djam'an, dkk. 2011. Profesi Keguruan. Jakarta: Universitas terbuka

Wardani, IGAK, Wihardit, Kuswaya, Nasution. 2011. Penelitian Tindakan Kelas. Jakarta: Universitas Terbuka

Winataputra, Udin S, dkk. 2013. Materi dan pembelajaran IPS SD. Tanggerang Selatan : Universitas Terbuka.

Winkel, WS. 1984. Psikologi Pendidikan dan Evaluasi. Jakarta: Gramedia. 